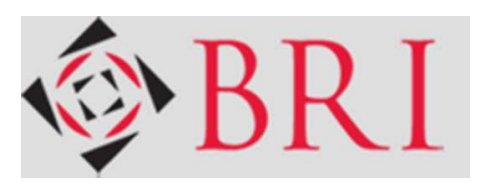

\title{
Clearing the air on EU guidance projects for school buildings
}

\begin{tabular}{|r|l|}
\hline Journal: & Building Research \& Information \\
\hline Manuscript ID & 17BR1331-IN.R1 \\
\hline Manuscript Type: & Information Paper \\
\hline Keywords: & energy efficiency, indoor air quality, thermal comfort, schools \\
\hline Other keywords: & $\begin{array}{l}\text { Professionals engaged in the design of new or retrofit of existing school } \\
\text { buildings currently struggle finding comprehensive guidelines to achieve } \\
\text { healthy and energy efficient school environments. Recently two major and } \\
\text { independent research projects aimed at improving indoor environmental } \\
\text { quality and energy performance of school buildings in Europe have been } \\
\text { completed: SINPHONIE and School of the Future. Their guidelines reflect } \\
\text { the distinct priorities and limited scope of each project. This paper } \\
\text { compares for the first time and, as far as possible, synthesises these } \\
\text { outputs to facilitate their use in practice and research. Overall, SINPHONIE } \\
\text { is most useful in addressing indoor environmental quality of schools in } \\
\text { terms of the physical, chemical, and microbiological stressors that impact } \\
\text { and potentially affect human health. It aims to influence the future } \\
\text { development of policy and regulations. By contrast, School of the Future } \\
\text { presents a broader design oriented approach based on best practice in four } \\
\text { European countries. For the most part they complement each other in their } \\
\text { recommendations, however this review highlights several areas that } \\
\text { require further clarification and research including links between indoor } \\
\text { environmental quality and cognitive performance, the consequent } \\
\text { appropriate level for the designed ventilation rate, and the role of adaptive } \\
\text { thermal comfort in schools. }\end{array}$ \\
\hline Abstract
\end{tabular}

\section{SCHOLARONE $^{\text {th }}$}

Manuscripts 


\section{Clearing the air on EU guidance projects for school buildings}

Professionals engaged in the design of new or retrofit of existing school buildings currently struggle finding comprehensive guidelines to achieve healthy and energy efficient school environments. Recently two major and independent research projects aimed at improving indoor environmental quality and energy performance of school buildings in Europe have been completed: SINPHONIE and School of the Future. Their guidelines reflect the distinct priorities and limited scope of each project. This paper compares for the first time and, as far as possible, synthesises these outputs to facilitate their use in practice and research. Overall, SINPHONIE is most useful in addressing indoor environmental quality of schools in terms of the physical, chemical, and microbiological stressors that impact and potentially affect human health. It aims to influence the future development of policy and regulations. By contrast, School of the Future presents a broader design oriented approach based on best practice in four European countries. For the most part they complement each other in their recommendations, however this review highlights several areas that require further clarification and research including links between indoor environmental quality and cognitive performance, the consequent appropriate level for the designed ventilation rate, and the role of adaptive thermal comfort in schools.

Key words: indoor air quality; thermal comfort; school buildings; energy efficiency.

\section{Introduction}

School buildings typically pose considerable challenges to meet demanding and interrelated design requirements in terms of high occupant densities, indoor air quality (IAQ), and energy performance. Ensuring delivery of IAQ is essential for children, as it can impact the long-term health and cognitive performance of this vulnerable group (De Gids, Van Oel, Phaff \& Kalkman, 2007; Lee et al., 2012; Chatzidiakou, Mumovic \& Summerfield, 2012). 
Both new school building projects and refurbishment projects face increasingly strict building codes and regulations to improve their energy performance and reduce carbon emissions. In addition, schools are often seen by local authorities as an opportunity to showcase sustainable design in the community, which places yet further obligations to ensure that the resultant buildings do indeed act as positive exemplars in practice.

Designers, engineers, developers, and school authorities need to be familiar with the implications of various design and construction strategies and the synergies between them, so that the sustainability objectives can be reached. Clear, comprehensive, and evidence-based guidelines are therefore invaluable for these professionals. Much of the professional guidance currently available is based on the description of case studies that present various approaches for sustainable design or retrofit of schools (e.g. the Teenergy project on High-energy efficiency schools in Mediterranean Area (Teenergy Schools, 2009). Although a useful resource for design professionals in understanding the range of solutions being applied, these do not necessarily have corresponding information on the key objectives and specifications for IAQ, including expected ventilation rates, nor empirical evidence of what was achieved to determine the relative merits of each approach. In this context, the completion of two major European projects that included data collection as part of the assessment of the indoor environmental and energy and sustainability outcomes for schools represents a considerable step forward and has led to distinct sets of guidelines for design and education professionals.

Nevertheless, there are various areas where they coincide and confirm best practices of projects in several countries.

The first, Schools Indoor Pollution and Health: Observatory Network in Europe (SINPHONIE), established a scientific and technical network across the EU with the long-term objective of improving the standard of air quality in schools and 
kindergartens. At the same time, the project aimed to support future policy development by formulating guidelines, recommendations, and risk management options for better IAQ and associated health outcomes in schools. SINPHONIE was initiated and funded by the European Parliament, ran from 2010 to 2012, and studied 114 school in 21 EU member states and Albania, Bosnia and Herzegovina, Norway, and Serbia (SINPHONIE, 2016a).

The second, School of the Future - Towards Zero Emissions with High Performance Indoor Environment, was funded under the $7^{\text {th }}$ Framework Programme of the European Union and ran from 2011 to 2016. Its main objectives were the design, realisation, evaluation, and communication of good examples of future high performance buildings through the energy efficient renovation of four school buildings in Denmark, Germany, Italy, and Norway based on the contributions from 13 partners with experts in different fields (Erhorn-Kluttig, 2016) (School of the Future - Towards Zero Emission with High Performance Indoor Environment, n.d.).

A key part of the current design process is framed by CEN Standard EN15251 Indoor environmental input parameters for design and assessment of energy performance of buildings (European Norm, 2007), which assists with settings for indoor air quality and the thermal environment to determine the corresponding ventilation rates and related energy demand. (The standard also covers acoustics and lighting.) With a key objective to providing recommendations to improve existing standards, SINPHONIE has focussed on monitoring of IAQ and health in schools across the EU. For instance findings from the project contributed to the 2015 review, School environment: policies and current status, undertaken by the EU regional office of the World Health Organization (World Health Organization - WHO Regional Office for Europe, 2015). In contrast, the School of the Future project has focussed on exemplar 
retrofits in each of four countries to identify best practice in existing standards and guidelines for those countries and thereby develop practical tools for design, retrofit, and operation of schools across a range of sustainability goals (including IAQ). So while it is clear that the two projects complement each other in their scope and objectives, there is also overlap in interest regarding the indoor environment, particularly in relation to the application of EN15251 and determining ventilation rates.

The aim of this paper is to organise and synthesise the main recommendations from the guidelines of these two major EU projects in light of existing standards. It also identifies a number of key issues that remain unresolved which have emerged from evidence since the projects commenced.

\section{Comparison of EU School Guidelines}

\subsection{Indoor air quality}

In terms of IAQ schools require special attention, since children still have developing lungs and are more vulnerable to airborne pollutants than adults. Furthermore, they spend much of their time indoors while at school (Eurostat, 2011) and may not have fully developed the ability to communicate or act upon their concerns or discomfort in response to poor IAQ (Chatzidiakou et al., 2012). Even if the local school has unsatisfactory indoor environment, children are typically unable to choose to attend an alternative. For example, the review by Wargocki and Wyon (2017) identified several studies that linked poor IAQ with high levels of student absenteeism.

In addition to occupant related effects, IAQ is impacted by numerous pollutants; from indoor sources, such as furniture, construction materials, surface products, cleaning detergents, and uncontrolled humidity leading to mould growth. Major sources of external pollutants include traffic exhaust in urban areas and those associated with 
environmental conditions, such as pollen levels, and agricultural activities in rural areas. Furthermore, the overall pattern of variation in levels of each pollutant reflects factors related to building operation and management, including cleaning schedules that can release pollutants and re-suspend particulates and the timing of mechanical ventilation or window opening practices.

Both projects, but particularly SINPHONIE with a strong epidemiologic perspective and an extensive assessment program, highlighted established health impacts due to aspects of poor IAQ. However, the issue of cognitive function and academic performance of students, which is of particular relevance for understanding IAQ in schools, is less clearly identified. This may have reflected the relative lack of evidence at the time when the projects were undertaken and the difficulty in conducting studies with robust findings, such as accounting for socioeconomic factors in performance. Some studies, however, have recognised that cognitive function and performance should be considered as a key outcome as part of setting IAQ standards. For instance, in an extensive investigation of the renovations of school classrooms that allowed for accounting of confounding factors, Stafford showed a significant impact on performance in standardised tests (reading, mathematics) in rooms with initially poor IAQ that were renovated (Stafford, 2015). In a recent case-control study of office workers in the US in green certified buildings matched with standard office buildings, workers recorded markedly higher cognitive performance, controlling for annual earnings, job category and level of schooling than those in non-certified buildings (MacNaughton et al., 2017). Although the results also indicated this may be due to broader environmental factors beyond IAQ, the authors suggest that the productivity and health benefits identified may be of greater significance economically than from 
energy and carbon savings. As will be seen in the sections below, some evidence is also emerging for the effects of specific components of IAQ on cognitive performance.

\subsubsection{Carbon dioxide}

Building regulatory frameworks usually address ventilation rates based on the objective of limiting carbon dioxide $\left(\mathrm{CO}_{2}\right)$ concentration levels, since these are generally considered as providing a useful indicator for controlling a broad range of indoor pollutants, such as bio-effluents. This is not the case, however, for some classes of pollutants, especially those from external sources, such as $\mathrm{NO}_{2}$ and particulate matter from traffic (Chatzidiakou, Mumovic \& Summerfield, 2015).

The monitoring surveys from SINPHONIE found that Central, Eastern and Southern Europe had a high percentage of classrooms with $\mathrm{CO}_{2}$ levels higher than 1500 ppm, whilst in Northern and Western Europe a high percentage presented levels lower than 1000 ppm (SINPHONIE, 2016b). Although no specific level is recommended as a limit for standards, SINPHONIE advocates that classrooms should be equipped with monitor alarms that signal when the $\mathrm{CO}_{2}$ levels increase above a set level to alert that ventilation should be initiated (as is already the practice in some EU countries). Again rather than specify a strict limit for $\mathrm{CO}_{2}$, the guidelines just suggests $700 \mathrm{ppm}$ as an example to trigger the alarm and remedial ventilation, which is a surprisingly low figure given the previous discussion of standards in the range of $1000-1500 \mathrm{ppm}$ and potentially impractical if the ventilation systems have not been designed to meet that figure.

In its report on Indoor Environmental Quality (IEQ), School of the Future similarly indicates that for the four investigated countries, the recommended average $\mathrm{CO}_{2}$ concentration limit during occupied times ranges from $1000-1500 \mathrm{ppm}$, depending on the national guidelines (School of the Future - Towards Zero Emission 
with High Performance Indoor Environment, 2016b). With its focus on sustainable design options, the use of $\mathrm{CO}_{2}$ monitors are presented in the context of ventilation strategies and reducing energy demand, which is discussed further below.

Again when considering academic performance, the weight of recent evidence suggests that a stricter approach to $\mathrm{CO}_{2}$ levels may be warranted. In a recent double blind study design of office workers, Allen et al. (2016) found a dose response whereby most domains of cognitive function declined substantially as $\mathrm{CO}_{2}$ levels were raised from $550 \mathrm{ppm}$ to $945 \mathrm{ppm}$ and then to $1400 \mathrm{ppm}$. A technical review of the relationship of IAQ in schools and cognitive function alongside other indicators, such as absenteeism, suggests that the IAQ design target should be to keep $\mathrm{CO}_{2}$ levels below $1000 \mathrm{ppm}$, rather than considering the $1500 \mathrm{ppm}$ as an acceptable upper bound (Chatzidiakou, Mumovic \& Dockrell, 2014).

\subsubsection{Volatile Organic Compounds}

Volatile organic compounds (VOCs) are organic chemicals that have a high vapour pressure at normal room temperature. They occur in numerous variations and some play an important role in nature (Guenther, 1995), but some are dangerous to human health or cause harm to the environment. Indoor VOCs usually emerge from products such as paints, coverings or adhesives. Their high concentration levels can cause severe respiratory, allergic, or immune effects in children (Mendell, 2007). Despite these effects, there are no harmonized EU guidelines for accepted indoor VOCs levels. In terms of exposure, SINPHONIE and School of the Future guidelines coincide in their recommendations specifically for formaldehyde, a gas released from woodbased materials and component of paints, glues and textiles. They suggest following the World Health Organisation (WHO) 2010 IAQ recommendations that, in order to avoid both short term irritation and long term health consequences for both adults and 
children, formaldehyde concentrations should not exceed an average of $0.1 \mathrm{mg} / \mathrm{m}^{3}$ exposure over a $30 \mathrm{~min}$ period.

SINPHONIE guidelines do not provide any overall accepted level for indoor concentrations of total volatile organic compounds (TVOCs). By way of contrast, School of the Future note the lack of clarity or even absence of regulations in some European countries. These guidelines cite the German Federal Environmental Agency, which endorses keeping concentration values lower than $0.3 \mathrm{mg} / \mathrm{m}^{3}$; even though this is higher than the WHO recommendation for formaldehyde. To avoid reaching $1 \mathrm{mg} / \mathrm{m}^{3}$, it is recommended to increase ventilation. For higher values, the specific sources of the pollutants would require a further assessment.

In terms of avoiding the problem from the outset, both sets of guidelines advise the use of certified low-emitting construction products and materials in school buildings as best practice in order to limit TVOCs to levels that minimise the associated risks to the health of children and school staff.

\subsubsection{Other pollutants}

Besides $\mathrm{CO}_{2}$ and TVOCs there are numerous other pollutants that affect the IAQ in school buildings. SINPHONIE investigated an extensive range of physical, chemical and microbiological stressors from different sources that can negatively affect IAQ.

The outcomes of SINPHONIE highlight important patterns of interrelations between these factors, exposure, sources/causes and health impacts on students. Therefore, it proposes first to use indicators that can identify which symptoms experienced by the students are linked to IAQ problems; for example if the symptoms are widespread within a class or school or if they disappear when the occupants leave the building at the end of a school season. Then it offers a set of indicators, tools, and protocols for monitoring IAQ and evaluating health in a school environment. Table 1 
summarizes the main SINPHONIE recommendations for the identified physical and chemical stressors. In terms of microbiological stressors, SINPHONIE also recommends to pay attention to fungi resulting from mould and bacteria from inadequate cleaning.

It is worth noting that a number of pollutants, which are only briefly mentioned in one or both projects, have recently attracted attention due to studies across Europe that have found potential exposures at unsafe levels. Toxic substances, such as phthalates and naphthalenes, can be present on children's toys, modelling clay, waxes, paints, and soft plastics, amongst others, and can cause endocrine disruptions (United States Green Building Council [USGBC], 2016). SINPHONIE mentions that limited studies have been conducted on this matter and no results have been published. For now, they recommend the guideline value of $10 \mu \mathrm{g} / \mathrm{m}^{3}$, as established by the WHO.

A similar situation is arising around Radon. Studies in Italy and Greece have shown that Radon is present in schools with mid to high levels. In the province of Lecce, Italy for example, 438 schools were evaluated and their annual average concentration was $209 \mathrm{~Bq} / \mathrm{m}^{3}$, with a variation from $21 \mathrm{~Bq} / \mathrm{m}^{3}$ to $1608 \mathrm{~Bq} / \mathrm{m}^{3}$. About $7 \%$ of the schools showed Radon concentration values above $500 \mathrm{~Bq} / \mathrm{m}^{3}$ (Trevisi, Leonardi, Simeoni, Tonnarini \& Veschetti, 2012). In Greece, a similar study was conducted in 512 schools in 8 of the 13 regions of Greece and the average value was $149 \mathrm{~Bq} / \mathrm{m}^{3}$ with a maximum of $958 \mathrm{~Bq} / \mathrm{m}^{3}$ (Clouvas, Xanthos, Takoudis, 2011).

SINPHONIE mentions in its Annex B that the RADPAR (Radon Prevention and Remediation) project should be consulted in order to prevent Radon contamination, but gives no further recommendations. The main indoor source of Radon is the soil, but it can also be found in water and building materials. Therefore, the main prevention strategies concern mostly new buildings, where Radon-proof membranes in the 
foundations and other Radon-resistant techniques should be implemented. A number of organizations, including the WHO and the German Federal Office for Radiation Protection recommend a maximum value of $100 \mathrm{~Bq} / \mathrm{m}^{3}$.

\subsection{Thermal Comfort}

The perception of thermal comfort is directly influenced by a combination of personal factors, including metabolic rate and clothing level, and environmental factors such as air temperature, mean radiant temperature, air speed, and humidity (Chartered Institution of Building Services Engineers [CIBSE], 2008). Both sets of guidelines highlight the importance of a comfortable indoor environment and provide consistent recommendations on the main variables that should be considered to achieve it (summarized in Table 2).

In terms of operative temperatures, radiation asymmetry and draught risk, both projects agree with their advice on appropriate measures, though School of the Future is the more expansive on methods to achieve improved internal comfort and provides a benchmarking tool to compare with the requirements and standards of the four participating countries of the project. Guidelines from both projects also recommend that external and internal heat gains should be reduced by measures, such as external shading devices, low-E coatings on glazing, and energy efficient lighting and equipment, in order to avoid the risk of overheating.

Although further research is needed, the links between classroom temperature and the cognitive performance of students again suggest that there are significant benefits if 
design targets are set for the low end of the comfort range, i.e. $20-22{ }^{\circ} \mathrm{C}$ in winter and $22-24{ }^{\circ} \mathrm{C}$ in summer (Chatzidiakou, Mumovic \& Dockrell, 2014), since children have higher metabolic rate per kg body weight, and they are usually more active. Wargocki and Wyon have also shown that the performance in mathematical and language skills was significantly lower at $27^{\circ} \mathrm{C}$ and $30^{\circ} \mathrm{C}$ in comparison with $20^{\circ} \mathrm{C}$; this negative effect could be as great as 30\% (Wargocki \& Wyon, 2013) In their recent synthesis, Chatziadakou L. and colleagues identified an empirical dose response in improved combined cognitive performance (speed and accuracy) of more than $10 \%$ in going from $25^{\circ} \mathrm{C}$ to $20^{\circ} \mathrm{C}$. Kim and de Dear in 2018 have also estimated a preferred temperature to be $2-3 \mathrm{~K}$ below the neutrality predicted for adults under the same thermal environmental exposures (Kim \& de Dear, 2018).

While cooler indoor temperatures is advantageous for reduced space heating requirements in winter, it poses considerable challenges for energy efficient design strategies, such as with naturally ventilated buildings during summer in many parts of Europe. Neither SINPHONIE nor School of the Future, however, have fully addressed the trade-off between specific thermal adaptation of children and their schoolwork performance that has since been highlighted by Wargocki and Wyon (2017). The spectrum of thermal comfort adaptation strategies in school buildings requires further investigation and potential recommendations, especially with expected increases in temperature with climate change.

\subsection{Ventilation strategies}

In order to maintain good IAQ and thermal conditions, appropriate ventilation strategies and rates should be considered according to the circumstances of each school.

For the adequate ventilation of classrooms SINPHONIE recommends a healthbased ventilation rate defined and expressed as litres/second per person and no longer 
simply as air changes per hour $(\mathrm{ACH})$. Both projects suggest a minimum rate of $4 \mathrm{l} / \mathrm{s}$ per child, which using the EN 15251 standard for a typical classroom with $3 \mathrm{~m}$ ceiling height corresponds to a $\mathrm{CO}_{2}$ concentration of $1500 \mathrm{ppm}$. However, both projects also highlight the 1000 ppm limit, which this paper endorses as a maximum based on the evidence of effects of $\mathrm{CO}_{2}$ on cognitive function, and School of the Future identifies as a value of 7 1/s per child in a typical classroom.

To understand the basis of this figure using EN 15251, the total fresh air supply rate is determined with regard to the pollution sources (persons and materials) with one of three calculation methods: i) the sum of required fresh air supply for persons and building materials, ii) the highest value of both sources, or iii) the intermediate value between the first and second calculation result.

For classrooms, it fixes a default occupancy rate of $2 \mathrm{~m}^{2} /$ person and $\mathrm{CO}_{2}$ production of each child at $14 \mathrm{l} / \mathrm{h}$ to calculate a person-based ventilation rate of 3.5 $1 / \mathrm{sm}^{2}$, and according to the second calculation method (highest value of both sources), a ventilation rate of 7 1/s per child is recommended for new and modernised buildings with a normal level of expectancy for indoor air quality. Some jurisdictions, such as Norway, require an additional ventilation rate linked with materials (i.e. the first method of EN 15251), which in the case of a very low emissions building adds $0.71 / \mathrm{s}$ per person).

In practice, these figures will not be sufficient to ensure that the indoor environment is kept below the $1000 \mathrm{ppm}$ limit for $\mathrm{CO}_{2}$. First, classrooms are not exclusively used by children, apart from the possibility of occupancy by senior students (young adults), they may accommodate adult education in the evenings. The ventilation rate in the typical classroom calculation described above is $91 / \mathrm{s}$ per adult. Second, design calculations should allow for the possibility that occupancy rates for children in 
schools may on occasions be higher than $2 \mathrm{~m}^{2} /$ person. In this vein, in their synthesis, Chatziadakou L. and colleagues (2014) suggest a minimum fresh air supply rate of $8 \mathrm{l} / \mathrm{s}$ per person.

Both projects provide descriptions for a range of methods of ventilation.

SINPHONIE guidelines suggest that schools should be evaluated according to a range of factors, including the climatic zone, quality of the outdoor air, and external noise levels in the vicinity of the school building. Further, the reserve capacity of the heating system should allow for a rapid reheating of the classrooms after manual ventilation.

In terms of the outdoor air quality, it is important to mention that the EN 13779: Ventilation and air conditioning of non-residential buildings (European Norm, 2007) could be referenced. This standard classifies the air quality of indoor air, the supply air, exhaust air and the outside air, depending on various criteria in two to five classes.

The Table 3 shows the recommended $\mathrm{CO}_{2}$ indoor concentration according to the outside pollution levels and the Indoor Air Quality (IDA), where IDA 1 has a high indoor air quality and IDA 4 a low indoor air quality.

The guidelines from School of the Future present the advantages and disadvantages of natural, mechanical and hybrid ventilation systems. The guidelines advise using natural ventilation as far as possible in summer. Hence a mix-mode solution is suggested with natural ventilation in summer and mechanical ventilation in winter. A system, which is controlled automatically between these two modes, provides one of the best solutions for EU regions with cold winters and warm summers like Germany.

A high air exchange rate in summer contributes to thermal comfort with the reduction of the indoor air temperature, as long the outdoor temperature is lower than the indoor temperature. Additionally, it elevates the air velocity in a room, which can 
increase the maximum acceptable air temperature, if the occupants are able to control it. Therefore the air exchange rate in summer should be determined firstly for the provision of thermal comfort, rather than by air quality.

Both sets of guidelines also recommend the use of night ventilation to reduce the risk of overheating, with SINPHONIE also suggesting that for buildings with low thermal mass external insulation should be considered to support this strategy.

Regarding further passive cooling strategies, both projects mention the need for implementing enhanced day and night cooling with proper controls. In cases where a mechanical ventilation system is installed, School of the Future suggests that ground ducts can be used for precooling supply air. SINPHONIE on the other hand, highlights the need to look deeper into adaptive thermal comfort aspects, especially due the implications of future climatic conditions in European countries.

\subsection{Other factors: acoustics and lighting}

Both projects advise that the acoustic design of the entire school building should be customised by space (normal classrooms, music rooms, sports facilities, social areas, etc.), in order to achieve optimum working and learning conditions. Successful acoustic design is of particular importance for naturally ventilated and mixed mode buildings, since issues of noise (such as outside noise through open windows and vents) may lead the occupants to override building operational settings. While SINPHONIE gives no further specific recommendations, School of the Future advocates the use of the German Standard DIN 4109 for noise protection requirements against various kinds of acoustic disturbances, both outdoors and indoors. It also mentions that in most cases, the construction typology and the individual building components are selected under criteria that are not primarily guided by the aim of noise protection. Therefore it recommends special attention to the flanking transmission, which can result in small 
areas with unacceptable levels of noise. In terms of achieving high-quality indoor acoustics, School of the Future highlights reverberation time as key parameter due to its direct correlation with speech intelligibility. This variable can be quantified for classrooms according to the German Standard DIN 18041. However for assembly halls or gymnasiums, and for the impact of ventilation and mechanical systems on acoustics, it is recommended that experts evaluate these specific cases.

In terms of lighting conditions, School of the Future includes several recommendations, as part of the requirements to achieve high performing indoor environments and energy efficient buildings. For instance, it recommends that the lighting design follows EN 12464-1 in considering the specific requirements for each space and in addressing all the main design requirements together: the optimum lighting levels, the light distribution including glare limitation, and the colour-rendering index. Given its focus on IAQ, the SINPHONIE guidelines only refer to energy efficient lighting in order to reduce heating load and improve thermal comfort in summer.

\section{Discussion}

In the process of bringing together results from these two major EU projects on schools, that had quite different objectives, scope, and methods, it has become clear that to large extent they serve to complement each other in the overall guidance they provide. This is despite the fact that that neither project refers to the other. Moreover, this synthesis has suggested - particularly in light of the emerging evidence associated with IAQ and cognitive performance - that the key recommendations shared by the projects regarding design performance objectives around $\mathrm{CO}_{2}$ levels, operative temperatures, and ventilation rates should be set at the toughest limit or go beyond current standards. So apart from general design and operational strategies, schools still appear to pose 
considerable challenges in providing the IAQ needed while also meeting sustainable design and energy efficiency objectives that have yet to be fully resolved.

So, how should these sets of guidelines be used? Given that SINPHONIE involved a wider range of countries (22 across the EU) but focussed in more detail on issues related to IAQ, it provides a useful resource on country specific guidelines as well as a broad set of practical recommendations for healthy environments within European schools with a further view to their implementation as part of national legislation. To that end they have proposed four criteria to help national and local authorities to judge which policy measures relating to the implementation of the guidelines for healthy school environments are most appropriate for their situation: effectiveness, proportionality, practicability, and monitorability. Their recommendations on measures and associated costs, largely derived from the US Environmental Protection Agency, are particularly well suited to policymakers since the project provides a comprehensive view on common problems that are found in schools in terms of health and energy efficiency and how to tackle them taking into account the costs and other impacts.

In contrast, School of the Future focuses far more on identifying what might be termed as current best practice for practitioners - primarily those involved in design and retrofit. Demonstration projects are used to evaluate several broad strategies for highly energy efficient retrofitting of schools in four EU countries with different climates, with IAQ representing just one of the topics covered. The comparison of several projects can be found at the on-line Information Tool provided by School of the Future (School of the Future - Towards Zero Emission with High Performance Indoor Environment, 2016a). 
Specifically, School of the Future published three further guidelines (in addition to the "Indoor environmental quality in schools"): "Retrofit of building construction elements", "Retrofit of building services systems", and "Solution sets for zero emission/energy-surplus schools". So this set of guidelines provides designers and building authorities with descriptions and recommendations for several strategies to plan, design and construct or retrofit school buildings aiming towards high-energy efficiency and low emissions. For instance it has performed numerous calculations for various retrofit measures concerning energy savings, reduced $\mathrm{CO}_{2}$ emissions, investment costs, net present values and simple payback time vs. physical lifetime. The results are presented in the four reports for Germany, Italy, Denmark and Norway (School of the Future - Towards Zero Emission with High Performance Indoor Environment, 2014).

In addition, the School of the Future has compiled some training seminars for pupils, teachers and facility managers with the main goal to show what the three user groups can do to improve the energy efficiency and the indoor comfort of the school building during the operational phase. They are focussed on their application in the four countries of the School of the Future partners, but there is also a European level guidance in English available that can be adapted to other countries (School of the Future - Towards Zero Emission with High Performance Indoor Environment, 2015). For this group, SINPHONIE guidelines also contains a section on Tips for a healthy school environment which addresses the corresponding space of each school department, from classrooms to gyms and science labs, with their relevant elements (such as blackboards, furniture, science tools, sport equipment, amongst others), as well as general ventilation strategies in each case. 
As noted above, ventilation remains a key design and operational issue that remains far from fully resolved. SINPHONIE is somewhat unclear on the rationale beyond its passing suggestion - rather than definitive guidance - for classroom monitors for $\mathrm{CO}_{2}$ to be set at $700 \mathrm{ppm}$, and we suspect likely impractical in the classroom. However, the growing evidence identified here and elsewhere on the impact on cognitive performance supports the position of going beyond current standards. Designers and building operators need to ensure systems should be put in place, whether they are natural or mechanical ventilation or a hybrid approach, capable of keeping $\mathrm{CO}_{2}$ levels below $1000 \mathrm{ppm}$. This review has also argued that indoor temperatures also need to be kept at the low end of the recommended range to avoid detrimental effects on cognitive function. Furthermore, it is essential that a strategy of natural ventilation in summer deals with issues related to the external environment, including outdoor air quality and noise pollution, which can be commonplace in the urban school context.

These issues suggest that Category I in EN 15251, which is characterized as "High level of expectation and is recommended for spaces occupied by very sensitive and fragile persons with special requirements like handicapped, sick, very young children and elderly persons", might be more appropriate for school pupils than Categories II or III. These considerations pose further challenges in terms of designing and planning natural or hybrid ventilation systems, beyond those needed for mechanical ventilation systems. Their design requires a high degree of expertise, which is not found by just following the usual standards and regulations (Wagner et al, 2015). Therefore, the guidelines should advise on the participation of a competent professional in this field in the early planning process, to analyse to what extent a natural ventilation system can be implemented, in order to reduce energy consumption while achieving good IAQ. 
Two further points need to be addressed in future school guidelines. First, Life Cycle Assessment (LCA) is a basic concept for green buildings and is increasingly relevant in refurbishments, targeting the most efficient solutions from a long-term perspective. LCA is a method that accounts for the environmental impacts associated with construction - including the embodied energy of the materials - long-term operations and maintenance, as well as with resultant monetary costs and savings. LCA needs to be brought explicitly into the process for the sustainable design and retrofit of schools.

Second, both projects also recommend Occupant Indoor Environmental Quality Surveys, although under different approaches. SINPHONIE generally describes the sort of information that should be gathered from the different target groups, such as teachers, pupils, parents and managers, and recommends implementing absenteeism protocols and tests for assessing concentration. By way of contrast, School of the Future provides an Occupant Questionnaire for Complaint Discovery with measurement instructions, which are focused on thermal comfort, lighting, room acoustics and noise protection.

These two approaches should be integrated, with discrepancies resolved, to produce a standard core methodology and set of questions for the assessment and monitoring of the indoor environment of schools. Furthermore, beyond IAQ and energy efficiency, other more holistic aspects of school design need to be incorporated as part of best practice, for instance the design principals from Barrett, and colleagues (2016) of naturalness, individualization, level of stimulation, and design flexibility and posited as resulting in improved learning outcomes 


\section{Conclusions}

The guidelines and tools produced from both projects complement one another and represent a major step forward in the approach to the design of new and retrofit of existing school buildings. This paper has brought much of that information together as a stepping-stone for further investigation on design standards and strategies as needed. SINPHONIE is more suitable for professionals who want to identify, avoid or solve problems related to IAQ in the learning environments and their health consequences. In this regard it sets the stage for policy and regulatory development at the EU level. School of the Future has more relevance for design and construction professionals in terms of understanding the range of strategies for delivering sustainable and energy efficient designs based on current best practice evident as exemplified in four demonstration projects.

Schools are often intended to act as exemplars in sustainable design for the wider community. Both projects already acknowledge that further work is needed to deliver the best outcomes, but this is particularly the case when aiming to deliver school environments that are beyond current IAQ standards and in light of the future challenges that will be posed by climate change. Specifically, since many schools in the EU are not contemplating to introduce mechanical systems for the summer, there is a necessity to identify and evaluate innovative techniques that improve thermal comfort and other aspects of IAQ, but have limited impact on energy consumption.

\section{References}

Allen J.G., MacNaughton P., Satish U., Santanam S., Vallarino J., Spengler J.D. (2016) Associations of cognitive function scores with carbon dioxide, ventilation, and volatile organic compound exposures in office workers: a controlled exposure 
study of green and conventional office environments. Environ Health Perspect 124, 805-812. [Online] Retrieved from: http://dx.doi.org/10.1289/ehp.1510037.

Chartered Institution of Building Services Engineers [CIBSE] (2008) CIBSE Concise Handbook. London: CIBSE.

Chatzidiakou L., Mumovic D., Summerfield A. (2012) What do we know about indoor air quality in school classrooms? A critical review of the literature. Intelligent Buildings International 4, 228 - 259, DOI: 10.1080/17508975.2012.725530.

Chatzidiakou L., Mumovic D., Dockrell J. (2014) The Effects of Thermal Conditions and Indoor Air Quality on Health, Comfort and Cognitive Performance of Students. The Bartlett, UCL Faculty of the Built Environment UCL Institute for Environmental Design and Engineering. London: Built Offsite.

Chatzidiakou L., Mumovic D., Summerfield A. (2015) Is $\mathrm{CO}_{2}$ a good proxy for indoor air quality in classrooms? Part 1: The interrelationships between thermal conditions, $\mathrm{CO}_{2}$ levels, ventilation rates and selected indoor pollutants. Building Services Engineering Research \& Technology 36(2), 129-161.

Clouvas A., Xanthos S., Takoudis G. (2011) Indoor radon levels in Greek schools. Journal of Environmental Radioactivity 102, 881 - 885.

De Gids W.F., Van Oel C.J., Phaff J.C., Kalkman A. (2007) Het effect van ventilatie op de cognitieve prestaties van leerlingen op een basisschoo. [The effect of ventilation on the cognitive performance of students at an elementary school]. 1. TNO Bow en Onderground. TNO report 2006-D-1078/B. (in Dutch)

Erhorn-Kluttig H. (2016) BUILD UP - The European portal for energy efficiency in buildings (2016) OVERVIEW - School buildings as leading examples of energy efficient renovation [Online] Retrieved from: http://www.buildup.eu/en/news/overview-school-buildings-leading-examplesenergy-efficient-renovation-0 . 
European Norm (2007) EN 13779:2007. Ventilation and air conditioning of nonresidential buildings.

European Norm (2007) EN 15251:2007. Indoor environmental input parameters for design and assessment of energy performance of buildings addressing indoor air quality, thermal environment, lighting and acoustics.

Eurostat (2011) School enrolment and levels of education.

Guenther A., Hewitt C.N., Erickson D., Fall R., Geron C., Graedel T., Harley P., Klinger L., Lerdau M., McKay W.A., Pierce T., Scholes B., Steinbrecher R., Tallamraju R., Taylor J., Zimmerman P. (1995) A global-model of natural volatile organic-compound emissions. Journal of Geophysical ResearchAtmospheres100, 8873-8892.

Lee M.C., Mui K.W., Wong L.T., Chan W.Y., Lee E.W.M., Cheung C.T. (2012) Student learning performance and indoor environmental quality (IEQ) in airconditioned university teaching rooms. Building and Environment 49, 238-244.

MacNaughton P., Satish U., Cedeno Laurent J.C., Vallarino J., Coull B., Spengler J.D., Allen J.G., Flanigan S. (2017) The impact of working in a green certified building on cognitive function and health. Building and Environment 114, 178186.

Mendell M.J. (2007) Indoor residential chemical emissions as risk factors for respiratory and allergic effects in children: A review. Indoor Air 17 (4), 259 -77.

Kim J., de Dear R. (2018) Thermal comfort expectations and adaptive behavioural characteristics of primary and secondary school students. Building and Environment 127, 13-22.

School of the Future - Towards Zero Emission with High Performance Indoor Environment (n.d.) About School of the Future [Online] Retrieved from: http://www.school-of-the-future.eu/index.php/about. 
SINPHONIE (2016a) Schools Indoor Pollution and Health: Observatory Network in Europe [Online] Available

School of the Future - Towards Zero Emission with High Performance Indoor Environment (2014) Technology screening [Online] Retrieved from: http://www.school-of-the-future.eu/index.php/project-results/technologyscreening.

School of the Future - Towards Zero Emission with High Performance Indoor Environment (2015) Tailored training [Online] Retrieved from: http://www.school-of-the-future.eu/index.php/project-results/tailored-training.

School of the Future - Towards Zero Emission with High Performance Indoor Environment (2016a) Information Tool. [Online] Retrieved from: https://www.school-of-the-future.eu/informationtool/\#StartMain.

School of the Future - Towards Zero Emission with High Performance Indoor Environment (2016b) Web tool: Assessment of temperatures and $\mathrm{CO}_{2}$ level. [Online] Retrieved from: http://www.school-of-thefuture.eu/informationtool/\#ComfortBenchmark. http://sinphonie recorg/

SINPHONIE (2016b) Guidelines for healthy environments within European schools [Online] Retrieved from: http://sinphonie.rec.org/

Stafford, T. M. (2015) Indoor air quality and academic performance. Journal of Environmental Economics and Management 70, 34-50.

Teenergy Schools (2009) High energy efficiency schools in Mediterranean Area Guidelines [Online] Retrieved from: http://teenergy.commpla.com/content/teenergy-guidelines. 
Trevisi R., Leonardi F., Simeoni C., Tonnarini S., Veschetti M. (2012) Indoor radon levels in schools of South-East Italy. Journal of Environmental Radioactivity $112,160-164$.

United States Green Building Council [USGBC] (2016) Green Classroom Professional Certificate Program. Wshington: US Green Building Council.

Wagner A., Höfker G., Lützkendorf T., Moosman C., Schakib-Ekbatan K., Schweiker M. (2015) User Satisfaction in office buildings - Recommendations for planning and operation (in German). FIZ Karlsruhe. BINE Informationsdienst, Bonn. Stuttgart: Fraunhofer IRB.

Wargocki P., Wyon D. P. (2013) Providing better thermal and air quality conditions in school classrooms would be cost-effective. Building and Environment 59, 581589.

Wargocki P., Wyon D. P. (2017) Ten questions concerning thermal and indoor air quality effects on the performance of office work and schoolwork. Building and Environment 112, 359 - 366.

World Health Organization - WHO Regional Office for Europe (2015) School environment: policies and current status [Online] Retrieved from: http://www.euro.who.int/ data/assets/pdf file/0009/276624/Schoolenvironment-Policies-current-status-en.pdf. 
Table 1: Summary of SINPHONIE's ANNEX B: Physical and chemical stressors relevant to the indoor school environments

\begin{tabular}{|c|c|c|c|c|}
\hline Stressor & Description & Common sources & Standard / Guideline & Further recommendation for schools \\
\hline $\begin{array}{l}\text { Particulate } \\
\text { Matter: } \\
\mathrm{PM}_{2.5} \text { and } \\
\mathrm{PM}_{10}\end{array}$ & $\begin{array}{l}\text { Airborne particulate matter is a } \\
\text { composite of many different } \\
\text { substances that exist as particles, } \\
\text { which are quite heterogeneous. }\end{array}$ & $\begin{array}{l}\text { Outdoors: construction } \\
\text { sites, fields. } \\
\text { Indoors: textiles. }\end{array}$ & $\begin{array}{l}\text { WHO 2005: } \mathrm{PM}_{2.5}: 25 \mu \mathrm{g} / \mathrm{m}^{3} \text { average } \\
\text { as a 24-hour and } 10 \mu \mathrm{g} / \mathrm{m}^{3} \text { as an } \\
\text { annual average. } \mathrm{PM}_{10}: 50 \mu \mathrm{g} / \mathrm{m}^{3} \\
\text { average as a 24-hour and } 20 \mu \mathrm{g} / \mathrm{m}^{3} \\
\text { annual average. }\end{array}$ & $\begin{array}{l}\text { Minimise idling by transportation } \\
\text { vehicles in the vicinity of school } \\
\text { buildings. }\end{array}$ \\
\hline Benzene & $\begin{array}{l}\text { Benzene is an organic chemical } \\
\text { compound and a natural } \\
\text { constituent of crude oil. It is } \\
\text { widely used as an industrial } \\
\text { solvent. }\end{array}$ & $\begin{array}{l}\text { Outdoors: exhaust from } \\
\text { motor vehicles, tobacco } \\
\text { smoke. } \\
\text { Indoors: paints, } \\
\text { varnishes. }\end{array}$ & $\begin{array}{l}\text { Benzene is classified by the } \\
\text { International Agency for Research on } \\
\text { Cancer (IARC) as a known human } \\
\text { carcinogen, hence no save level of } \\
\text { exposure can be recommended. }\end{array}$ & $\begin{array}{l}\text { Indoor concentrations should not } \\
\text { exceed the outdoors' levels. } \\
\text { Minimise idling by transportation } \\
\text { vehicles in the vicinity of school } \\
\text { buildings. }\end{array}$ \\
\hline $\begin{array}{l}\text { Nitrogen } \\
\text { dioxide } \\
\left(\mathrm{NO}_{2}\right)\end{array}$ & $\begin{array}{l}\mathrm{NO}_{2} \text { is a chemical compound } \\
\text { emitted from combustion } \\
\text { processes and produced by } \\
\text { photochemical reactions. It is a } \\
\text { strong oxidant with a } \\
\text { characteristic pungent odour. }\end{array}$ & $\begin{array}{l}\text { Outdoors: exhaust from } \\
\text { motor vehicles. }\end{array}$ & $\begin{array}{l}\text { WHO 2010: } 40 \mu \mathrm{g} / \mathrm{m}^{3} \text { annual and } \\
\text { weekly average and } 200 \mu \mathrm{g} / \mathrm{m}^{3} \text { in } 1 \\
\text { hour. }\end{array}$ & $\begin{array}{l}\text { Minimise idling by transportation } \\
\text { vehicles in the vicinity of school } \\
\text { buildings. }\end{array}$ \\
\hline $\begin{array}{l}\text { Carbon } \\
\text { monoxide } \\
\text { (CO) }\end{array}$ & $\begin{array}{l}\text { CO is a colourless, odourless and } \\
\text { non-reactive gas. It is a product of } \\
\text { incomplete combustion although } \\
\text { some industrial and biological }\end{array}$ & $\begin{array}{l}\text { Outdoors: exhaust from } \\
\text { motor vehicles, tobacco } \\
\text { smoke. } \\
\text { Indoors: space heaters. }\end{array}$ & $\begin{array}{l}\text { WHO 2010: } 100 \mathrm{mg} / \mathrm{m}^{3}(15 \mathrm{~min}), 60 \\
\mathrm{mg} / \mathrm{m}^{3} \text { (30min), } 30 \mathrm{mg} / \mathrm{m}^{3}(60 \mathrm{~min}), \\
10 \mathrm{mg} / \mathrm{m}^{3}(8 \mathrm{~h}), 7 \mathrm{mg} / \mathrm{m}^{3}(24 \mathrm{~h}) .\end{array}$ & $\begin{array}{l}\text { Careful maintenance of HVAC systems } \\
\text { and fuels use in the building. } \\
\text { Minimise idling by transportation } \\
\text { vehicles in the vicinity of school }\end{array}$ \\
\hline
\end{tabular}


processes also produce it.

Ozone $\left(\mathrm{O}_{3}\right) \quad \mathrm{O}_{3}$ is a gas naturally created in Indoors: printers. outdoor photo-oxidation

reactions by sunlight, and artificially created as a by product of human activities both out and indoors.

D- Limonene is a colourless liquid

limonene hydrocarbon obtained from citrus fruits.

Trichloroet TCE is a widely used industrial hylene solvent. It is a volatile, colourless

(TCE) liquid with a sweet chloroformlike smell.

Tetrachlor TCA is a readily volatile colourless orange fragrances. oethylene (TCA)

Radon

liquid with an ether-like smell widely used for dry cleaning of fabrics. of ionising radiation of natur major contributor the ionising radiation dose received by the general population in various indoor environments.

buildings.

WHO 2005: $100 \mu \mathrm{g} / \mathrm{m}^{3}(8 \mathrm{~h})$.

Keep laser printers and photocopying machines away from classrooms.

Reduce products based on citrus extracts.

Indoors: commonly An exposure limit of $450 \mu \mathrm{g} / \mathrm{m}^{3}$ was found in cleaning recommended by the EU-INDEX products such as hand Project in 2005. However, it was cleansers with lemon- stated that it was not possible to recommend this long-term exposure value as a guideline due to the lack of sufficient toxicological data.

Indoors: inks and paints. WHO 2010.

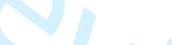

Indoors: inks, adhesives, cleaning fluids.

WHO 2010: 250 average.

$\mu \mathrm{g} / \mathrm{m}^{3}$ annual

Indoors: as by-product of the decay of radium in the soil subjacent to a building.

per $\mathrm{Bq} / \mathrm{m}^{3}$. WHO (2010)

recommended a residential
Based on WHO 2010, SINPHONIE estimated a unit risk of $4.3 \times 10^{-7}$ $\mu \mathrm{g} / \mathrm{m}^{3}$.

Keep laser printers and photocopying machines away from classrooms.

Keep laser printers and photocopying machines away from classrooms.

Monitor cleaning products for these substances.

The excess lifetime risk of death If a source is suspected, measure the from radon-induced cancer is $6 \times 10^{-4}$ indoor and outdoors levels.

reference level at $100 \mathrm{~Bq} / \mathrm{m}^{3}$. 
Table 2: Thermal comfort variables tackled by SINPHONIE and School of the Future

\begin{tabular}{|c|c|c|}
\hline Parameter & SINPHONIE Recommendations & $\begin{array}{lcll}\text { School of } & \text { the } & \text { Future } \\
\text { Recommendations } & & \\
\end{array}$ \\
\hline $\begin{array}{l}\text { Operative } \\
\text { Temperatures }\end{array}$ & $\begin{array}{l}\text { Room temperature should be } \\
\text { maintained throughout the year } \\
\text { according to the season between } \\
\text { approx. } 20^{\circ} \mathrm{C} \text { and } 26^{\circ} \mathrm{C} \text {. }\end{array}$ & $\begin{array}{l}\text { The recommendable temperature } \\
\text { ranges according to season are: } 20^{\circ} \mathrm{C} \text { - } \\
24^{\circ} \mathrm{C} \text { for winter and } 24^{\circ} \mathrm{C}-26^{\circ} \mathrm{C} \text { for } \\
\text { summer. }\end{array}$ \\
\hline $\begin{array}{l}\text { Thermal } \\
\text { radiation } \\
\text { asymmetry }\end{array}$ & $\begin{array}{l}\text { Walls, floors and ceilings must be } \\
\text { designed in such a way to prevent } \\
\text { unpleasant thermal radiation } \\
\text { exchange with cold surfaces. }\end{array}$ & $\begin{array}{l}\text { High performance envelopes, shading } \\
\text { devices and proper ventilation are } \\
\text { advisable in order to avoid radiation } \\
\text { asymmetry caused by cold surfaces. }\end{array}$ \\
\hline Draught risk & $\begin{array}{l}\text { Air-supply openings must not be } \\
\text { taped over to stop draughts. } \\
\text { Appropriate adjustments or } \\
\text { repairs should be carried out. }\end{array}$ & $\begin{array}{l}\text { Careful design of natural and } \\
\text { mechanical ventilation, including } \\
\text { passive cooling systems is required to } \\
\text { avoid draught risk and to reduce } \\
\text { energy consumption. }\end{array}$ \\
\hline Heat gains & $\begin{array}{l}\text { - Insulate the school building } \\
\text { fabric from outside. } \\
\text { - School buildings with a high } \\
\text { window-to-wall ratio can be } \\
\text { upgraded by using insulated } \\
\text { glazing panels and external } \\
\text { shading devices. } \\
\text { - Use Low-E coatings on glazing } \\
\text { to reduce infrared radiation. } \\
\text { - Use energy-efficient } \\
\text { equipment, light fittings, and } \\
\text { lighting strategies. }\end{array}$ & $\begin{array}{l}\text { - Use good external shading systems } \\
\text { and efficient equipment. } \\
\text { - Shading devices should be controlled } \\
\text { by total solar radiation on the façade } \\
\left(>150 \text { to } 300 \mathrm{~W} / \mathrm{m}^{2}\right) \text { and indoor } \\
\text { temperature also during the absence } \\
\text { of persons. } \\
\text { - Use of daylight should be considered } \\
\text { when designing the shading system }\end{array}$ \\
\hline
\end{tabular}


Table 3: Categories of indoor air quality (IDA) according to outside air $\mathrm{CO}_{2}$ concentration as in EN 13779

\begin{tabular}{lllll}
\hline Category & Outdoor $\mathrm{CO}_{2}$ & \multicolumn{4}{l}{ Absolute $\mathrm{CO}_{2}$ indoor concentration [ppm] } \\
& concentration [ppm] & $400 \mathrm{ppm}$ & $500 \mathrm{ppm}$ & $600 \mathrm{ppm}$ \\
\hline IDA 1 & $\leq 400$ & $\leq 800$ & $\leq 900$ & $\leq 1000$ \\
IDA 2 & $400-600$ & $800-1000$ & $900-1100$ & $1000-1200$ \\
IDA 3 & $600-1000$ & $1000-1400$ & $1100-1500$ & $1200-1600$ \\
IDA 4 & $>1000$ & $>1400$ & $>1500$ & $>1600$ \\
\hline
\end{tabular}

